\title{
EFFECT OF FEED SUPPLEMENTATION ON CHEMICAL COMPOSITION OF DUCK EGGS IN COASTAL AREAS OF BANGLADESH
}

\author{
M. M. Rahman ${ }^{1}$, M. J. Khan ${ }^{2}$, S. D. Chowdhury ${ }^{3}$ and M. A. Akbar ${ }^{2}$
}

\begin{abstract}
An experiment was conducted to investigate the effect of feed supplementation on chemical composition of Jinding duck's egg. A total of 180 physically sound eggs were randomly collected in each time at $50 \%$ and $75 \%$ level of egg production of the ducks. Significant difference was observed for dry matter content of egg albumen of ducks fed on different diets at $50 \%$ level of egg production $(\mathrm{P}<0.01)$ but no significant difference was recorded for dry matter content of egg yolk at $50 \%$ level of egg production $(\mathrm{P}>0.05)$. The $\mathrm{CP}$ contents of egg albumen and egg yolk differed significantly $(\mathrm{P}<0.01)$ at $50 \%$ level of egg production but the difference was not significant $(\mathrm{P}>0.05)$ for $\mathrm{CP}$ content of egg yolk at $75 \%$ level of production. There were significant differences $(\mathrm{P}<0.01)$ on EE and TA contents of egg albumen and egg yolk at all levels of production. The results of the study demonstrated that the dry matter, as well as crude protein, ether extract and total ash content of eggs on dietary treatment $\mathrm{T}_{1}$ (Scavenging + standard ration ) was highest compared to the eggs on other treatment groups $\left(T_{0}, T_{2}\right.$, $\mathrm{T}_{3}, \mathrm{~T}_{4}$ and $\mathrm{T}_{5}$ ).
\end{abstract}

Key words: Feed supplementation, Chemical composition, Jinding duck, Scavenging, Coastal areas.

\section{Introduction}

Duck keeping is one of the possible means of breaking out of poverty trap of resource-poor smallholder families in low income countries (Pym et al., 2002). The duck eggs contain relatively less water and higher percentage of proteins and fats in the yolk, albumen and total contents of egg as compared to chicken eggs. Duck eggs served as a "current coin" to the poor farmers and house wives who can use it for education and health care of their children. Moreover, egg is the most inevitable animal protein source for the physical and mental development of children and helps to protect themselves from many other diseases. The quality of egg depends on physical make up and chemical composition of its constituent namely egg shell, albumen and yolk (USDA, 2002). The egg quality is the most important price contributing factor in table and hatching eggs. Therefore, the economic success of a

\footnotetext{
${ }^{1}$ Poultry Geneticist, Regional Poultry Farm, Rajshahi, Department of Livestock Services, Bangladesh

${ }^{2}$ Professor, Department of Animal Nutrition, Bangladesh Agricultural University, Mymensingh -2202

${ }^{3}$ Professor, Department of Poultry Science, Bangladesh Agricultural University, Mymensingh -2202
}

(Received: November 09, 2010) 
Bang. J. Anim. Sci. 2010, 39(1\&2)

laying flock solely depends on the total number of quality eggs produced (Monira et al., 2003). Many factors are responsible for egg quality including the environmental factors, breed, type of bird, age or bird, nutrition level of the flock and season of the year (Card and Nesheim, 1966 and Naber, 1979). Egg quality is also influenced by genetic and non-genetic factors as season, environment and feed intake (Salahuddin and Howlider, 1991).

Variability in the composition of eggs due to the composition of the diet fed to the laying bird exists for a number of nutrients (Naber, 1979). Yin et al. (2000) observed that CP levels had no significant effect on egg quality but increasing dietary methionine had little effect on egg quality characteristics (He et al., 2003). The fat content of the egg is easily changed by dietary manipulation of the laying bird (Naber, 1979). The nutrition of the bird does not appear to have any great effect on albumen quality (Naber, 1979) but the inclusion of fermentation residues such as brewer's grains or distiller's feed in the diet has been reported to improve egg albumen quality (Jensen et al., 1978a). The maintenance of the egg quality from the time of their production till their delivery to the final consumer is of great importance. Information on chemical composition of eggs laid by Jinding ducks under scavenging condition is scarce. It is necessary to know the quality of duck eggs for consumer's satisfaction. Therefore, the present experiment was undertaken to study the effect of feed supplementation on chemical composition of eggs laid by Jinding ducks under scavenging system of rearing in coastal areas Bangladesh.

\section{Materials and Methods}

The experiment was conducted for a period between October, 2003 and August, 2004 in three villages of Ramgati upazilla viz., Purba Kolakupa, Char Kolakupa and Char Poragacha in the district of Lakshmipur. A total of one hundred forty four, 4-month old Jinding ducks were reared up to the age of 12 months.

\section{Experimental design and treatments}

The ducks were randomly assigned to 6 treatment groups having 3 replicates in each treatment. Each replicate consisted of 8 ducks. All the birds wee supplied mash feed in addition to allowing them for scavenging.

\section{Feeding and management}

A standard ration was prepared using corn, rice polish , wheat bran, meat meal, soybean meal, mustard oil cake, common salt, vitamin-mineral premix, oyster shell and soybean oil, well mixed and supplied to the ducks belonged to treatment $T_{1}$ group. Similar quantity of rice polish, broken rice, a mixture of rice polish and broken rice $(1: 1)$ and rice polish, broken rice and wheat bran (5:3:2) wee supplied to the ducks of $T_{2}, T_{3}, T_{4}$ and $T_{5}$ treatments, respectively. The amount of supplemental feeds were divided into two equal halves and were given twice daily (7.30 A.M. and at 5.30 P.M.). All ducks were vaccinated against Duck Plague and Duck Cholera. The experimental birds were allowed to scavenge freely in the agricultural fields, ponds and ditches near to farmer's house for 9 hours (8.00 A.M. to 
5.00 P.M.). Feeds were supplied in the bowls in the form of wet mash and the bowls were cleaned properly before each feeding time. Sufficient clean drinking water was also supplied in bowls in each time of feeding. Proper care and management practices were followed by the researcher and farmers throughout the experimental period.

\section{Collection of egg sample}

The freshly laid eggs of Jinding ducks were collected from the farmers. The eggs were collected in two times, once at 50\% and other at 75\% level of egg production of Jinding ducks. Five numbers of eggs were taken from each treatment at each level of production. Each time of collection, all the eggs were identified properly with individual serial number. For this purpose, a total number of 180 eggs were collected randomly from 6 treatments groups at $50 \%$ and $75 \%$ level of egg production.

\section{Chemical analysis}

Dry matter (DM), crude protein (CP), ether extract (EE) and total ash (TA) content of eggs were done following the principles of AOAC (2004).

\section{Statistical analysis}

Data were analyzed statistically using analysis of variance technique for a completely randomized design and significant differences among the treatment means were identified by Duncan’s Multiple Range Test (Steel and Torrie, 1980).

\section{Results and Discussion}

The dry matter, crude protein, ether extract and total ash contents of eggs (egg albumen) are given in Table 1. The highest DM content of egg albumen was found in $\mathrm{T}_{1}$ group (12.67) followed by $\mathrm{T}_{3}$ (12.04), $\mathrm{T}_{4}$ (11.89), $\mathrm{T}_{5}$ (11.61), $\mathrm{T}_{2}$ (11.47) and $\mathrm{T}_{0}$ (11.44) treatment groups at all levels of egg production. The difference in dry matter content of egg albumen among the treatment groups was not significant $(\mathrm{P}>0.05)$. The DM content of egg albumen found in the present experiment is in well agreement with the findings of Mountney and Parkhurst (2001); Li-Chang et al. (2002); Sreenivasaiah (1986) and Rose et al. (1966) but the present value was much lower than the values reported by Prasad (2000) and Das (1999). Higher percentage of albumen dry matter in $\mathrm{T}_{1}$ group may be explained by the fact that large eggs tend to have a higher proportion of albumen (Marion et al., 1964).

The CP content of egg albumen varied from 9.62 to 11.10. The highest CP content of egg albumen was found in $\mathrm{T}_{1}$ group (11.10) as compared to other treatment groups at all levels of egg production. The difference in CP content of egg albumen between the treatment groups $\mathrm{T}_{0}$ and $\mathrm{T}_{2}$ was not significant ( $\left.\mathrm{P}>0.05\right)$ at $50 \%$ level of egg production. The CP content of egg albumen found in the present study is in well agreement with the observation of Stadelman and Cotterill (2002); Mountney and Parkhurst (2001); Cunningham et al. (1960) 
Bang. J. Anim. Sci. 2010, 39(1\&2)

and Leeson and Summers (1997). But the result was higher than the findings of Prasad (2000). Chung and Stadelman (1965) found that the protein content of albumen increased by $0.09 \mathrm{~g}$ for each gram increase in egg weight, which partially support the present result and the differences wee significant $(\mathrm{P}<0.05)$ at $75 \%$ level of egg production.

The EE content of egg albumen on dietary treatment $\mathrm{T}_{1}$ (standard ration) was highest compared to other treatment groups $T_{0}$ (only scavenging), $T_{2}$ (Scavenging with rice polish), $\mathrm{T}_{3}$ (scavenging with broken rice), $\mathrm{T}_{4}$ (Scavenging with rice polish and broken rice) and $\mathrm{T}_{5}$ (Scavenging with rice polish, broken rice and wheat bran). The difference in EE content of egg albumen among the treatment groups $\mathrm{T}_{0}, \mathrm{~T}_{2}$ and $\mathrm{T}_{5}$ was not significant $(\mathrm{P}>0.05)$ at $50 \%$ level of egg production but it was statistically significant $(\mathrm{P}<0.01)$ at $75 \%$ level of egg production. The EE content of egg albumen found in this experiment is almost similar to the findings of Cunningham et al. (1960), Stadelman and Cotterill (2002) and Mountney and Parkhurst (2001) but the result of the present findings is lower than the value reported by Sreenivasaiah (1986).

The content of inorganic elements in egg albumen as ash ranged between 0.49 and 0.71 and the variation observed in ash content of egg albumen was highly significant $(\mathrm{P}<0.01)$ among the treatment groups at all levels of egg production. The TA content of egg albumen found in this experiment is in close association with the findings of Stadelman and Cotterill (2002, Mountney and Parkhurst (2001); Prasad (2000) and Leeson and Summers (1997). The dry matter, crude protein, ether extract and total ash contents of eggs (egg yolk) are given in Table 2.

The DM content of egg yolk on dietary treatment $\mathrm{T}_{1}$ (standard ration) was highest compared to other treatment groups $T_{0}, T_{2}, T_{3}, T_{4}$ and $T_{5}$. There was no significant difference ( $\left.P>0.05\right)$ for DM contents of egg yolk of ducks fed on different diets at $50 \%$ level of egg production. The dry matter content of egg yolk is almost similar to the findings of Mountney and Parkhurst (2001) and Sreenivasaiah (1986).

The CP content of egg yolk ranged between 15.86 and 16.68\%. The CP content of egg yolk varies significantly $(\mathrm{P}<0.01)$ at $50 \%$ level of egg production but did not differ at $75 \%$ at level of egg production $(\mathrm{P}>0.05)$. There was no significant difference $(\mathrm{P}>0.05)$ for $\mathrm{CP}$ content of egg yolk of ducks fed on different diets at all levels of egg production. The CP content of egg yolk found in this experiment is slightly lower than the findings of Mountney and Parkhurst (2001); Stadelman and Cotterill (2002) and Cunningham et al. (1960) but the present value was slightly higher than the findings of Prasad (2000). The CP content of egg yolk found in $\mathrm{T}_{1}$ treatment group is in close association to the findings of Leeson and Summers (1997). 
The EE content of egg yolk on dietary treatment $\mathrm{T}_{1}$ (standard ration) was highest (35.05) compared to other treatment groups $\mathrm{T}_{0}$ (only scavenging), $\mathrm{T}_{2}$ (Scavenging with rice polish), $\mathrm{T}_{3}$ (scavenging with broken rice), $\mathrm{T}_{4}$ (Scavenging with rice polish and broken rice) and $\mathrm{T}_{5}$ (Scavenging with rice polish, broken rice and wheat bran). The EE content of egg yolk varied from 31.52 to $35.05 \%$ which is in well agreement with the finding of Sreenivasaiah (1986), Stadelman and Cotterill (2002) and Leeson and Summers (1997). Although significant difference $(\mathrm{P}<0.01)$ was observed for EE content of egg yolk of ducks but the difference in EE content of egg yolk between the treatment groups $T_{1}$ and $T_{3}$ was not significant $(\mathrm{P}>0.05)$ at $50 \%$ level of egg production. Similarly, no significant difference $(\mathrm{P}>0.05)$ was found between the treatment groups $\mathrm{T}_{2}$ and $\mathrm{T}_{5}$ at $75 \%$ level of production.

Table 1. Chemical composition of Jinding duck egg (egg albumen) in different treatment groups (g/100g DM)

\begin{tabular}{|c|c|c|c|c|c|c|c|c|c|}
\hline \multirow[t]{2}{*}{ Parameters } & \multirow{2}{*}{$\begin{array}{c}\text { Level of } \\
\text { egg prodn. }\end{array}$} & \multicolumn{6}{|c|}{ Dietary treatments ${ }^{\#}$} & \multirow[t]{2}{*}{ SED } & \multirow{2}{*}{$\begin{array}{l}\text { Level } \\
\text { of Sig. }\end{array}$} \\
\hline & & $\mathbf{T}_{\mathbf{0}}$ & $\mathbf{T}_{1}$ & $\mathbf{T}_{2}$ & $\mathbf{T}_{3}$ & $\mathbf{T}_{4}$ & $\mathbf{T}_{5}$ & & \\
\hline \multirow[t]{2}{*}{ Dry matter } & $50 \%$ & $11.43^{\mathrm{a}}$ & $12.65^{\mathrm{a}}$ & $11.45^{\mathrm{a}}$ & $11.99^{\mathrm{a}}$ & $11.88^{\mathrm{a}}$ & $11.60^{\mathrm{a}}$ & 0.69 & $* *$ \\
\hline & $75 \%$ & 11.45 & 12.69 & 11.48 & 12.08 & 11.89 & 11.62 & 0.49 & NS \\
\hline Average & - & 11.44 & 12.67 & 11.47 & 12.04 & 11.89 & 11.61 & - & - \\
\hline \multirow[t]{2}{*}{ Crude protein } & $50 \%$ & $9.53^{\mathrm{d}}$ & $10.98^{\mathrm{a}}$ & $9.65^{\mathrm{d}}$ & $10.25^{\mathrm{b}}$ & $10.08^{\mathrm{bc}}$ & $9.82^{\mathrm{cd}}$ & 0.15 & $* *$ \\
\hline & $75 \%$ & $9.70^{\mathrm{b}}$ & $11.21^{\mathrm{a}}$ & $10.00^{\mathrm{b}}$ & $10.68^{\mathrm{ab}}$ & $10.43^{\mathrm{ab}}$ & $10.18^{\mathrm{b}}$ & 0.42 & $*$ \\
\hline Average & - & 9.62 & 11.10 & 9.83 & 10.47 & 10.26 & 10.00 & - & - \\
\hline \multirow[t]{2}{*}{ Ether extract } & $50 \%$ & $0.04^{\mathrm{d}}$ & $0.13^{\mathrm{a}}$ & $0.05^{\mathrm{d}}$ & $0.11^{\mathrm{b}}$ & $0.08^{\mathrm{C}}$ & $0.06^{\mathrm{d}}$ & 0.008 & $* *$ \\
\hline & $75 \%$ & $0.05^{\mathrm{e}}$ & $0.15^{\mathrm{a}}$ & $0.08^{\mathrm{de}}$ & $0.13^{\mathrm{b}}$ & $0.09^{c}$ & $0.09^{\mathrm{d}}$ & 0.008 & $* *$ \\
\hline Average & - & 0.05 & 0.14 & 0.07 & 0.12 & 0.09 & 0.08 & - & - \\
\hline \multirow[t]{2}{*}{ Total ash } & $50 \%$ & $0.47^{\mathrm{d}}$ & $0.69^{\mathrm{a}}$ & $0.52^{\mathrm{cd}}$ & $0.63^{\mathrm{b}}$ & $0.58^{\mathrm{bc}}$ & $0.55^{\mathrm{c}}$ & 0.03 & $* *$ \\
\hline & $75 \%$ & $0.51^{\mathrm{e}}$ & $0.72^{\mathrm{a}}$ & $0.55^{\mathrm{de}}$ & $0.68^{\mathrm{ab}}$ & $0.62^{\mathrm{bc}}$ & $0.58^{\mathrm{cd}}$ & 0.03 & $* *$ \\
\hline Average & - & 0.49 & 0.71 & 0.54 & 0.66 & 0.60 & 0.57 & - & - \\
\hline
\end{tabular}

${ }^{\#} \mathrm{~T}_{0}=$ Only scavenging, $\mathrm{T}_{1}=$ Scavenging + standard ration, $\mathrm{T}_{2}=$ Scavenging + rice polish, $\mathrm{T}_{3}=$ Scavenging + broken rice, $\mathrm{T}_{4}=$ Scavenging + rice polish and broken rice (1:1) and $\mathrm{T}_{5}=$ Scavenging + rice polish + broken rice and wheat bran $(5: 3: 2)$

SED = Standard Error of Deviation

a, b, c, d, e Values having common superscripts in the same row did not differ significantly $(\mathrm{P}>0.05)$

The TA content of egg yolk ranged between 1.03 and $1.20 \%$ and the variation observed in ash content of egg yolk was highly significant $(\mathrm{P}<0.01)$ at $50 \%$ level of egg production. The TA content of egg yolk found in this experiment is well agreed to the findings of Stadelman 
Bang. J. Anim. Sci. 2010, 39(1\&2)

and Cotterill (2002); Leeson and Summers (1997) and Prasad (2000) and lower than the values reported by Mountney and Parkhurst (2001).

Table 2. Chemical composition of Jinding duck egg (egg yolk) in different treatment groups (g/100g DM)

\begin{tabular}{|c|c|c|c|c|c|c|c|c|c|}
\hline \multirow[t]{2}{*}{ Parameters } & \multirow{2}{*}{$\begin{array}{l}\text { Level of } \\
\text { egg prodn. }\end{array}$} & \multicolumn{6}{|c|}{ Dietary treatments ${ }^{\#}$} & \multirow[t]{2}{*}{ SED } & \multirow{2}{*}{$\begin{array}{l}\text { Level } \\
\text { of Sig. }\end{array}$} \\
\hline & & $\mathbf{T}_{\mathbf{0}}$ & $\mathbf{T}_{1}$ & $\mathbf{T}_{2}$ & $\mathbf{T}_{3}$ & $\mathbf{T}_{4}$ & $\mathbf{T}_{5}$ & & \\
\hline \multirow[t]{2}{*}{ Dry matter } & $50 \%$ & 51.53 & 53.57 & 51.77 & 52.75 & 52.42 & 52.32 & 0.67 & NS \\
\hline & $75 \%$ & $51.59^{\mathrm{b}}$ & $53.64^{\mathrm{a}}$ & $51.80^{\mathrm{b}}$ & $52.79^{\mathrm{ab}}$ & $52.55^{\mathrm{ab}}$ & $52.41^{\mathrm{ab}}$ & 0.56 & $*$ \\
\hline Average & - & 51.56 & 53.61 & 51.79 & 52.77 & 52.49 & 52.37 & - & - \\
\hline \multirow[t]{2}{*}{ Crude protein } & $50 \%$ & $15.84^{\mathrm{a}}$ & $16.63^{\mathrm{a}}$ & $15.89^{\mathrm{a}}$ & $16.40^{\mathrm{a}}$ & $16.23^{\mathrm{a}}$ & $16.12^{\mathrm{a}}$ & 0.51 & $* *$ \\
\hline & $75 \%$ & 15.87 & 16.73 & 15.98 & 16.45 & 16.33 & 16.21 & 0.29 & NS \\
\hline Average & - & 15.86 & 16.68 & 15.94 & 16.43 & 16.28 & 16.17 & - & - \\
\hline \multirow[t]{2}{*}{ Ether extract } & $50 \%$ & $31.48^{\mathrm{b}}$ & $34.98^{\mathrm{a}}$ & $31.95^{b}$ & $34.15^{\mathrm{a}}$ & $32.46^{\mathrm{b}}$ & $32.34^{\mathrm{b}}$ & 0.70 & $* *$ \\
\hline & $75 \%$ & $31.56^{\mathrm{d}}$ & $35.12^{\mathrm{a}}$ & $31.98^{\mathrm{cd}}$ & $34.21^{\mathrm{b}}$ & $32.54^{c}$ & $32.40^{\mathrm{cd}}$ & 0.41 & $* *$ \\
\hline Average & - & 31.52 & 35.05 & 31.97 & 34.18 & 32.50 & 32.37 & - & - \\
\hline \multirow[t]{2}{*}{ Total ash } & $50 \%$ & $1.01^{\mathrm{f}}$ & $1.14^{\mathrm{a}}$ & $1.03^{\mathrm{e}}$ & $1.10^{\mathrm{b}}$ & $1.07^{\mathrm{c}}$ & $1.05^{\mathrm{d}}$ & 0.008 & $* *$ \\
\hline & $75 \%$ & $1.04^{\mathrm{C}}$ & $1.26^{\mathrm{a}}$ & $1.05^{\mathrm{c}}$ & $1.14^{\mathrm{b}}$ & $1.08^{\mathrm{b}}$ & $1.09^{\mathrm{bc}}$ & 0.03 & $* *$ \\
\hline Average & - & 1.03 & 1.20 & 1.04 & 1.12 & 1.08 & 1.07 & - & - \\
\hline
\end{tabular}

${ }^{\#} \mathrm{~T}_{0}=$ Only scavenging, $\mathrm{T}_{1}=$ Scavenging + standard ration, $\mathrm{T}_{2}=$ Scavenging + rice polish, $\mathrm{T}_{3}=$ Scavenging + broken rice, $\mathrm{T}_{4}=$ Scavenging + rice polish and broken rice $(1: 1)$ and $\mathrm{T}_{5}=$ Scavenging + rice polish + broken rice and wheat bran (5:3:2)

SED = Standard Error of Deviation

a, b, c, d Values having common superscripts in the same row did not differ significantly $(\mathrm{P}>0.05)$

\section{Conclusion}

The results indicated that the dry matter, crude protein, ether extract and total ash contents of egg albumen and egg yolk are higher in 75\% level of egg production over 50\% level of egg production. The results of the study also demonstrated that the dry mater, as well as crude protein, ether extract and total ash content of egg albumen and egg yolk on dietary treatment $\mathrm{T}_{1}$ (Scavenging + standard ration ) was highest compared to the eggs of other treatment $\left(\mathrm{T}_{0}\right.$, $\mathrm{T}_{2}, \mathrm{~T}_{3}, \mathrm{~T}_{4}$ and $\mathrm{T}_{5}$ ) groups.

\section{Literature Cited}

AOAC. 2004. Association of the Official Agricultural Chemists. Official Methods of Analysis. Washington, DC, 1-34pp.

Card, L. E. and Nesheim, M. C. 1966. Poultry production $10^{\text {th }}$ edn. Leo \& Pebiger. 
Chung, R. A. and Stadelman, W. J. 1965. A study of variations in the structure of the hen's egg. British Poult. Sci., 6: 277-282.

Cunningham, F. E., Cotterill, O. J. and Funk, E. M. 1960. The effect of season and age of bird. 2. On the chemical composition of egg white. Poult. Sci., 39: 300-308

Das, S. K. 1999. Poultry production. CBS publishers \& distributors, Darya Gonj, New Delhi, p. 192.

He, J. H., Li, J. B., Gao, F. X., Liu, Q. H., Shu, J. C. and Liu, D. J. 2003. Dietary methionine requirement of the Chinese egg-laying duck. British Poult. Sci., 44(5): 741-745.

Jensen, L. S., Chang, C. H. and Wilson, S. P. 1978a. Interior egg quality: improvement by distillers feeds and trace elements. Poult. Sci., 57: 648-654.

Leeson, S. and Summers, J. D. 1997. Commercial poultry nutrition. $2^{\text {nd }}$ ed. University Books, Guelph, Ontario, 184 p.

Li-Chang, E.C.Y., Powrie, W.D. and Nakai, S. 2002. The chemistry of eggs and egg products. In: Egg Science and Technology. William J. Stadelman and Owen J. Cotterill, pp. 109-110.

Marion, W.W., Nordskog, A.W., Tolman, H.S. and Forsythe, R.H. 1964. Egg composition as influenced by breeding, egg size, age and season. Poultry Science 43: 255-264.

Monira, K.N., Salahuddin, M. and Miah, G. 2003. Effect of breed and holding period on egg quality characteristics of chicken. Intl. J. Poult. Sci., 2(4): 261-263.

Mountney, G.J. and Parkhurst ,C.R. 2001. Poultry Products Technology. 386 p.

Naber, E.C. 1979. The effect of nutrition on the composition of eggs. Poult. Sci., 58: 518-528.

Prasad, J. 2000. Poultry production and management. Kalyani publishers. Ludhiana, New Delhi, pp. 234-235

Pym, R. A. E., Lanada, E. B. and Morbos, E. Y. 2002. Case studies of families poultry Development $2^{\text {nd }}$ INFPD-FAO, Electr. Conf.

Rose, D., Gridgeman, N.T. and Hetcher, D. A. 1966. Solids content of eggs. Poult. Sci., 45: 221-226.

Salahuddin, M. and Howlider, M. A. R. 1991. Effect of breed and season on egg quality traits of fowl. Indian J. Anim. Sci., 61: 859-863.

Sreenivasaiah, P.V. 1986. Nutritive value of eggs. Poult. Adv., 19(12): 41-43.

Stadelman, W. J. and Cotterill, O. J. 2002. Egg Sci. Technol., p. 110.

Steel, R.G.D. and Torrie, J.H.. 1980. Principles and procedures of statistics. Mc Graw-Hill Book Co. Inc., USA.

United States Department of Agriculture (USDA). 2002. Nutrient database for standard reference, 15, August.

Yin, Z., Yu, D., Yin, Z. Z. and Yu, D. Y. 2000. A study on the optimum dietary crude protein level for laying Shao ducks. J. Hebei Agril. Univ., 23(2): 13-16. 